\author{
Research Article \\ (C) 2020 Etor et.al.. \\ This is an open access article licensed under the Creative Commons \\ Attribution-NonCommercial 4.o International License \\ (https://creativecommons.org/licenses/by-nc/4.0/)
}

Received: 31 October 2019 / Revised: 11 December 2019 / Accepted: 15 December 2019 / Published: 10 January 2020

\title{
Management of Information and Communication Technology and Teachers' Work Performance in Secondary Schools in Cross River State, Nigeria
}

\author{
Dr. Mrs. Comfort R. Etor \\ Dr. (Mrs.) Usen F. Mbon \\ Dr. E. E. Ekanem \\ Department of Educational Management, \\ Faculty of Education, University of Calabar, \\ Etagbor, PMB 1115 Calabar 2018, Nigeria
}

Doi: 10.36941/mjss-2020-0007

\section{Abstract}

\begin{abstract}
The aim of the study was to investigate the relationship between management of Information and Communications Technology (ICT) and teachers' work performance in secondary schools in Cross River State, Nigeria. To achieve the purpose of the study, two research questions and one null hypothesis were formulated to guide the study. Survey research design was adopted for the study. The population of the study comprised of 5288 teachers in all the 271 public secondary schools in Cross River State, Nigeria. A sample of 800 teachers was drawn using stratified and simple random sampling techniques. Two instruments titled: Management of Information and Communications Technology Questionnaire (MICTQ) and Teachers' Work Performance Questionnaire (TWPQ) were used to collect data from the respondents. Data was analyzed using Pearson Product Moment Correlation at .05 level of significance and 798 degrees of freedom. The finding revealed that among the 12 principals' ICT management practices, only cleaning/dusting, arrangement of facilities and ventilation of ICT centres were significant. A positive significant relationship between Information and Communication Technology and teachers' work performance was also established ( $p<.05)$. Based on the finding, it was recommended amongst others that, there should be adequate supply of ICT facilities to secondary schools for effective utilization by teachers and students for quality teaching and learning.
\end{abstract}

Keywords: Management, teacher, secondary, performance, ICT

\section{Introduction}

Communication from time immemorial, has been viewed as an important tool for managing change and innovation in organizations. This is why when changes in communication technology are integrated into education produces knowledge and skills required for improvement in the educational system with impact on the society in general. Teachers are considered essential in the realization of educational goals, hence the effective performance of their work is a necessary condition for the success of the school system. To this end, teachers need to use Information and Communication Technology (ICT) to enhance their teaching effectiveness. There must be availability and prudent management of Information and Communication Technology resources by school principals and ensuring the proper utilization of these resources to boost teachers' work performance 
in schools. This is because the proper management of ICT facilities in institutions of learning is very paramount for execution of school activities by the school personnel especially the teachers. The school administrators are saddled with the responsibility of managing the scarce resources for the realization of educational objectives, hence the need for prudent management of ICT facilities such as computers, provision of internet services, example e-mail, WhatsApp, Facebook, Twitter, 2 go and a host of others to improve teachers' teaching effectiveness and students' learning outcome. Provision of ICT implies the procurement of the relevant facilities and ensuring their equitable distribution or allocation to all departments for use by teachers and students for teaching and learning. Beyond provision of ICT facilities, the school administrator has to monitor and coordinate their utilization to ensure that all teachers and students can access them for use as the need arises.

Another aspect of management of ICT by the school administrator is storage and maintenance. This implies that there must be appropriate storage facility or specified room for safe-keeping of all ICT facilities such as a laboratory in the school and a trained personnel assigned to oversee their uses and also accord appropriate maintenance periodically, to ensure their proper use and operational efficiency. Managing of ICT naturally include planning, provision and maintenance of ICT facilities in the school. By planning, it involves identifying types of ICT facilities needed to enhance teaching effectiveness by teachers, as well as for students to access to enhance their learning outcome.

Ogbonnaya (2017); Duru (2017); Ezekiel (2016); Isah and Adediji (2016) Osaat (2013) defined Information and Communication Technology as electronic technologies used in the creation, collection, storage, processing, retrieval, transmission of information between individuals for the benefit of the human race. Plomp, Pelgrum and Law (2007) noted that, ICT enables people to access knowledge and flow along with the latest development and societal dynamics. This shows that Information and Communication Technology may enable teachers and students to access course materials and carry out researches with ease. Ratheesonri (2018) also recognized Information and Communication Technology as technologies that provide access to information through telecommunication.

Furthermore, Anderson and Glen in Ossai and Isagua (2017) also stated that the integration of ICT in teacher training programmes is crucial in that teachers will gain knowledge in the use of ICT in teaching. This is true because an array of information on training can be retrieved from the internet and used in training of teachers. Akuegwu, Ntukidem, Ntukidem and Jaja (2012) also confirmed that, the knowledge-driven nature, powered by information technology, has made the place of Information and Communication Technology second to none in ensuring quality instructions in the universities. This means that Information and Communication Technology can be used by teachers to improve instructional activities at the various levels of education. Information and Communication Technology facilities such as computers, internet facilities, video computer disc, digital video disc, interactive white board, interactive television, close circuit television and radio increase the productivity of lecturers and secondary school teachers. These increase their interest in teaching, assist them in recognizing and restructuring their course(s); increase their emphasis on individualized instruction; provide teachers with opportunities to conduct experiments using emerging technologies, as a result of multi-media presence in the classroom; and also increase their opportunities to collaborate and network with colleagues Ubabudu and Murarina (2016); (Yusuf, 2005). The usefulness of these resources to teachers are many, but how many teachers are computer literate to benefit from it and become effective and productive? (Asodike, 2017; Harrison, 2013; Ajaji, 2008).

\section{Concept of Teachers' Work Performance}

Moreso, society believes that competent and effective teachers are important keys to a strong system of education. Accordingly, teachers are expected to be proficient in the use of instructional strategies, curriculum materials, educational technologies and classroom management techniques. They are also expected to have a thorough understanding of the developmental levels of their learners and maintain sound knowledge of the content they teach. To maintain and extend this high level of skill, teachers are expected to be informed of best practices and they ought to demonstrate the desire for 
professional development (National Council for Accreditation of Teacher Education) (NCATE, 2002). In the teaching and learning process, the use of Information and Communication Technology has to feature practically along with the theoretical aspect, hence, teachers need enough time to learn and explore Information and Communication Technology tools and gadgets to be able to use them confidently in the teaching and learning situation.

The teacher's work in the classroom is enormous and very demanding to produce the desired learning outcomes. Consequently, the teacher's work performance is predicated on sound knowledge of the subject-matter, effective classroom management and adoption of appropriate evaluation practices. This implies that only professionally trained teachers should be engaged to teach students at all levels of education. It is such training that will equip the teacher in his area of specialization in order to gain sound knowledge of the subject-matter for classroom instruction. Accordingly, a teacher that is well-versed in knowledge of the subject-matter will teach with confidence, and can adopt various or appropriate instructional strategies to enhance students' learning outcome. Besides, "students have to be equipped with knowledge and skills from the perspective of lifelong learning and of a learning society (especially through (ICT)" (Begiri, 2014:97; Anaduaka \& Okafor, 2013).

Classroom management is another professional practice that every teacher is expected to adopt to control unruly behaviour of students to ensure effective teaching and learning outcome. This requires the provision of instructional aides, such as Information and Communication Technology equipment in the classroom to further engage the attention and interest of students in the teaching-learning environment. Classroom management means mobilizing, organizing resources in the classroom as well as securing the cooperation of the learners for performing the functions of planning, organizing, organizing, directing and coordinating at classroom level by teachers (Ukala \& Nwabueze, 2015; Atanda 2009). Good classroom management makes learning easier. According to Nwadike and Godwins (2017) much frustration have been encountered in schools due to traditional method of managing classroom. The issue of ICT makes for easy programming, processing, editing, and accessing of information, proper record keeping, increase in e-learning and decrease in examination malpractice because in the installation of close circuit television in class and examination halls whatever the students do the teachers can easily see. This depends on the ability of the teacher to utilize those aids to ensure students' concentration and interest in the classroom (Ofodu, 2012).

Evaluation practices are key elements that ensure attainment of instructional outcome in students. Every teacher is therefore expected to adopt appropriate evaluation practices, during the classroom instruction and in evaluation by written examination and project writing. The attainment of the above variables of teacher's work performance may take time to be achieved without the provision of the relevant Information and Communication Technology apparatuses in the classroom. Besides, where the Information and Communication Technology equipment are available but the teachers are unable to use them, their performance is bound to be poor.

From observation, some teachers in secondary schools in Cross River State are lacking in carrying out their teaching jobs effectively. This implies that, the school administrator should provide teachers with the relevant ICT materials as well as ensure that they are duly trained to utilize these materials effectively in classroom instruction. Researchers' observations have shown that teachers' performance is below average as a result of non-exposure of teachers to the use of modern technology in teaching. Again, it has been observed that in most of the public secondary schools, teachers are not computer literate. In this regard, many teachers are still using only textbook to teach instead of browsing on the internet to get current materials that will enable them teach effectively as well as updating their knowledge in the subject matter. Some teachers do not have email addresses and those who have cannot open to check if they have messages, while some teachers often forget their usernames and passwords. Some do not listen to "news" and are not aware of things happening around, therefore they are not current to impact positively on the students. The effect of this inability of teachers to adapt to or access the modern technology in teaching have manifested in their poor performances as well as students' poor performance in internal and external examinations. Most teachers teach without using relevant instructional materials to explain difficult concepts to students 
while some cannot give assignment to students via email or WhatsApp. The ICT gadgets like audio and visual facilities are not installed in the classrooms for teachers and students to use.

In many instances, available computers in schools are usually confined to the laboratories, hence, the teachers have nothing to use to engage students to learn and eliminate disruptive behaviours in class. Teachers also feel that communicating with students through e-mail and WhatsApp constitute distraction to students. The problem of this study is therefore, the inability of school administrators to provide teachers with relevant ICT materials as well as ensure that they are duly trained to utilize these materials effectively in classroom instruction.

\section{Literature Review}

Many empirical studies on Information and Communication Technology exist. Some of them are reviewed based on their relevance to this study. Ghavifekr and Wan-Rosdy (2015) revealed that, Information and Communication Technology integration has a positive effect on both teachers and students. It was also revealed that, professional development programme for teachers play a key role in enhancing students' quality of learning (Ghavifekr \& Wan-Rosdy (2005). In the same vein, Ghaviferkr, Afshari, and Amla (2012) stated that, schools and other educational institutions that must prepare students to live in a knowledge society should integrate Information and Communication Technology into their school curriculum. This is because in contemporary era, technology integration has gone through innovations and has transformed our societies as well as changed the way people think, work and live. Integration of Information and Communication Technology in education is the introduction of computer-based communication into daily classroom instructional process (Grabe, 2007). The aim of Information and Communication Technology integration in education is to improve and increase the quality, accessibility, cost-efficiency of the delivery of instruction by the teachers to students (Oluyemisi, 2015).

In a study carried out by Chao (2015) it was discovered that lots of information on all subjects can be accessed by both teachers and students from the internet and that teachers should be given ample time to learn and acquire the Information and Communication Technology skills adequately. Adedoyin (2008) contended that, Information and Communication Technology improves the way instructional materials are used and makes instruction more efficient, less expensive and/or more accessible to the people. Information and Communication Technology provides flexible and effective ways for professional development of teachers, it improves in-service teacher training and also connects teachers to the global teacher community (Adedoyin, 2008). Accordingly, Information and Communication Technology training enables a teacher to acquire skills and knowledge in the effective use of ICT for better performance in teaching.

Oko and Uwatt (2015), revealed that: there is an enhancement of teachers' performance in lesson preparation and delivery through the use of Information and Communication Technology in Ogoja Education Zone. Davies (2009) also stated that teachers use ICT to prepare lesson note (that is, teachers search the internet and download relevant materials) for effective teaching. Similarly, the study of Wanjohi (2011) showed that ICT influenced the actual teaching and learning process positively. The study of Obeten and Ekpoh (2016) also showed that effective monitoring and supervision of school administrators and teachers on their application of ICT in teaching and learning will lead to knowledge integration for national development.

The study of Sigh and Munoadi (2012) revealed that inadequate power supply, lack of professional teachers to handle ICT facilities in schools, inadequate centres to keep the equipment and lack of proper maintenance as well as the attitude of principal and teachers who are not willing to change are the factors that militate against the effective utilization of ICT in schools. Olokola, Musa and Ajidagba (2015) revealed that inadequate power supply, inadequate computer and poor power supply constitute major problem in ICT usage in schools. The study of Williams, Uchendu and Mbon (2014) revealed that work performance in schools with sufficient ICT facilities was better than those in schools where ICT facilities were not available. The study of Ekpoh and Etor (2012) revealed 
that provision of ICT tools by university management was inadequate, majority of staff rated their ICT competence and utilization of ICT in knowledge creation activities as significantly low.

\section{Objectives of the Study}

The following objectives were the focus of this study:

i. To examine the Information and Communication Technology management practices adopted by principals in secondary schools

ii. To establish the relationship between Information and Communication Technology and teachers' work performance in secondary schools.

\section{Research Questions}

The following research questions were posed to direct the study:

i. What are the Information and Communication Technology management practices adopted by principals in secondary schools?

ii. To what extent does Information and Communication Technology relate to teachers' work performance in secondary schools?

\section{Research Hypothesis}

There is no significant relationship between Information and Communication Technology and teachers' work performance in secondary schools.

\section{Methodology}

Descriptive survey research design was adopted for the study. Survey research design involves the collection of data to accurately describe existing phenomenon (Isangedighi, Joshua, Asim \& Ekuri, 2004). This research design was considered appropriate because the study of Management of ICT and Teachers' Work Performance in Public Secondary Schools in Cross River State involves the collection of data which described the existing phenomena at the time of investigation and also ensured the adequate collection of information for the study.

The population of the study comprised all the teachers in public secondary schools in Cross River State, Nigeria. The population of teachers is 5288 comprising 2779 males and 2509 female teachers with 271 public secondary schools. Stratified and simple random sampling techniques were adopted for the study. The state was divided into three strata and the three Education Zones formed the three strata. From each strata, two Local Government Areas (LGA) were drawn making a total of 6 LGAs. From each LGA, 7 schools were drawn making a total of 42 schools and from each school 20 teachers were randomly drawn making a total of 840 as sample of the study. The administration of the instruments was carried out with the help of two research assistants. 40 copies of the questionnaires were either not returned or invalid due to incomplete filling, while 800 were used for the study.

The data for the study was collected with the use of two sets of instruments titled: "Management of Information and Communication Technology Questionnaire” (MICTQ) and Teachers' Work Performance Questionnaire (TWPQ). Management of ICT instrument was divided into two parts (Part A and Part B). Part A contained demographic data (respondents personal data) while Part B contains items on the management of ICT. The second instrument, teachers' work performance questionnaire was divided into two sections (sections A and B) and presented in the manner that the first instrument was presented. To establish the reliability of the instrument, the questionnaire was tested using thirty (30) teachers and twenty (20) students outside the study area. The odd and even numbered items were computed and correlated using split-half and adjusted using Spearman Brown Prophecy formula to obtain the appropriate estimate of reliability (o.84) of the tested items. 


\section{Results}

The descriptive analysis of the variables is presented in Table 1 as follows:

Table 1: Descriptive analysis of the variables

\begin{tabular}{clccc}
\hline S/N & Variables & $\mathrm{n}$ & $\overline{\mathrm{x}}$ & $\mathrm{SD}$ \\
\hline $\mathbf{1}$ & Information and Communication Technology & 800 & 18.825 & 4.951 \\
$\mathbf{2}$ & Knowledge of subject matter & 8 oo & 18.135 & 4.764 \\
3 & Classroom management & 8 oo & 17.793 & 4.566 \\
4 & Evaluation practices & 8 oo & 17.564 & 4.672 \\
\hline
\end{tabular}

\subsection{Research questions}

What are the ICT management practices adopted by principals in secondary schools? The result of the practices is presented in Table 2.

Table 2: Principals' ICT management practice $(\mathrm{n}=800)$

\begin{tabular}{clcccccccc}
\hline S/N & ICT management practices & Very often & Often & Rarely & Not at all & Mean & Rank & Remark \\
\hline 1 & Repairs & 153 & 309 & 155 & 183 & 2.54 & 8 & Not significant \\
2 & Cleaning/dusting & 330 & 281 & 104 & 85 & 3.07 & 3 & Significant \\
3 & Replacement & 277 & 288 & 127 & 108 & 2.92 & 4 & Not significant \\
4 & Ensuring proper utilization of ICT facilities & 203 & 214 & 265 & 118 & 2.63 & 7 & Not significant \\
5 & Ventilation of ICT laboratories & 416 & 269 & 79 & 36 & 3.33 & 2 & Significant \\
6 & Monitoring of users & 195 & 349 & 158 & 98 & 2.80 & 6 & Not significant \\
7 & Disposal of damaged facilities & 98 & 65 & 396 & 241 & 2.03 & 12 & Not significant \\
8 & Arrangement of facilities & 398 & 289 & 100 & 13 & 3.34 & 1 & Significant \\
9 & Regular inspection of ICT peripherals & 171 & 216 & 264 & 149 & 2.51 & 9 & Not significant \\
10 & Provision of internet services & 119 & 112 & 288 & 281 & 2.09 & 11 & Not significant \\
11 & Power supply & 165 & 144 & 257 & 234 & 2.30 & 10 & Not significant \\
12 & Software upgrading & 85 & 232 & 275 & 208 & 2.24 & 10 & Not significant \\
\hline
\end{tabular}

The acceptable mean was 3.00 and as such any that is less than 3.00 is considered not significant. The result in Table 2 revealed that out of the 12 ICT management practices, only cleaning/dusting, arrangements of facilities and ventilation of ICT centres were significant. The other 9 practices (repairs, replacement, monitoring of users, disposal of damaged facilities, regular checks/inspection of ICT peripherals, ensuring proper utilization of ICT, internet facilities, power supply and software upgrading) were not significant, implying that there were least practiced by the principals.

\subsection{Research hypothesis}

There is no significant relationship between management of Information and Communication Technology and teachers' work performance in secondary schools. The result is presented in Table 3.

Table 3: Summary of Pearson product correlation coefficient analysis of the relationship between management of Information and Communication Technology and teachers' work performance (knowledge of subject matter, classroom management and evaluation). ( $\mathrm{n}=8 \mathrm{oo})$

\begin{tabular}{clcccccc}
\hline S/N & Teachers' work performance & $\mathrm{n}$ & $\overline{\mathrm{x}}$ & $\mathrm{SD}$ & $\mathrm{df}$ & $\mathrm{r}$-cal. & Sign. \\
\hline 2 & Knowledge of subject matter & 800 & 18.135 & 4.764 & 798 & .793 & .000 \\
3 & Classroom management & 800 & 17.793 & 4.566 & 798 & .816 & .000 \\
4 & Evaluation practices & 800 & 17.564 & 4.672 & 798 & .784 & .000 \\
1 & Information and Communication Technology & 800 & 18.825 & 4.951 & & & \\
\hline $\mathrm{P}<.05, \mathrm{df}=798$ & & & & &
\end{tabular}


The result in Table 3 showed that $\mathrm{p}<.05$ at 798 degrees of freedom with knowledge of subject matter $(\mathrm{r}=.793, \mathrm{p}=.000)$, classroom management $(\mathrm{r}=.816, \mathrm{p}=.000)$ and evaluation practices $(\mathrm{r}=.784, \mathrm{p}=.000)$. By this result, the null hypothesis was rejected. This implies that there is a relationship between management of Information and Communication Technology and teachers' work performance in knowledge of subject matter, classroom management and evaluation.

\section{Discussion of Finding}

The finding on principals' management practices indicated that cleaning/dusting, arrangement of facilities and ventilation of ICT centres were significant. The least practiced were repairs, replacement, ensuring proper utilization of ICT facilities, monitoring of users, disposal of damaged facilities, regular checks/inspection of ICT peripherals, provision of internet facilities, power supply and software upgrading. This finding agree with the findings of Ghavifekr and Van Rosidy (2015) who conducted a study on teaching and learning with ICT integration in schools in Malaysia and found that ICT integration has a positive effect on both teachers and students. Obeten and Ekpoh (2016) also showed that effective monitoring and supervision of school administrators and teachers on their application of ICT in teaching and learning will lead to knowledge integration for national development.

Similarly, the study of Williams, Uchendu and Mbon (2014) revealed that work performance in schools with sufficient ICT facilities was better than those in schools where ICT facilities were not available. Furthermore, the finding is in line with the finding of Ekpoh and Etor (2012) whose study revealed that provision of ICT tools by university management was inadequate, majority of staff rated their ICT competence and utilization of ICT in knowledge creation activities as significantly low. Again, Olokola, Musa and Ajidagba (2015)'s study revealed that inadequate power supply, inadequate computer and poor power supply constitute major problem in ICT usage in schools.

The second result showed a significant relationship between ICT and teachers' work performance (knowledge of subject matter, classroom management and evaluation practices). The result revealed that knowledge of subject matter $(\mathrm{r}=.793, \mathrm{p}=.000)$, classroom management $(\mathrm{r}=.816$, $\mathrm{p}=.000)$ and evaluation practices $(\mathrm{r}=.784, \mathrm{p}=.000)$ significantly related to ICT management. This result is in line with the finding of Oka and Owan (2015) whose study on Information and Communication Technology (ICT) and Teachers' Work Performance in Primary Schools in Ogoja Education Zone, Cross River State, Nigeria revealed that the use of ICT enhanced teachers' performance in lesson preparation and delivery.

Similarly, Akuegwu, Ntukidem, Ntukidem and Jaja (2012) found that, the knowledge-driven nature, powered by information technology, has made the place of Information and Communication Technology second to none in ensuring quality instructions in the universities. This means that Information and Communication Technology can be used by teachers to improve instructional activities at the various levels of education. Information and Communication Technology facilities such as computers, internet facilities, video computer disc, digital video disc, interactive white board, interactive television, close circuit television and radio increase the productivity of lecturers and secondary school teachers. These increase their interest in teaching, assist them in recognizing and restructuring their course(s); increase their emphasis on individualized instruction; provide teachers with opportunities to conduct experiments using emerging technologies, as a result of multi-media presence in the classroom; and also increase their opportunities to collaborate and network with colleagues (Ubabudu \& Murarina, 2016).

\section{Conclusion}

Based on the findings, it was concluded that principals' ICT management practices with regards to repairs, replacement, monitoring of users, disposal of damaged facilities, regular checks/inspection of ICT peripherals, ensuring proper utilization, internet facilities, power supply and software upgrading 
were not significant. It was also concluded that Management of Information and Communication Technology has a positive significant relationship with teachers' work performance in terms of knowledge of subject matter, classroom management and evaluation practices. Teachers' work performance hinges on managerial ability of the school authorities to provide appropriate ICT facilities for use by teachers to enhance their work performance.

\section{Recommendations}

Based on the findings of the study, it was recommended that:

1. There should be adequate supply of ICT facilities to secondary schools for effective utilization by teachers and students for quality teaching and learning.

2. Principals should monitor to ensure that all teachers use ICT facilities regularly in the teaching and learning situation.

3. Teachers who are not able to use ICT facilities in the classroom should be trained and retrained for proper and effective utilization of the facilities.

4. The government should employ technologists in secondary schools whose mandate would be to train staff and the less informed school management team on the use of ICT resources for effective teaching and learning.

5. School administrators should also ensure that the ICT facilities are properly powered and maintained for effective use in instructional delivery as well as sourcing for information to enrich teachers' knowledge of the subject matter.

\section{References}

Abraham, N. M. (Ed.). Contemporary administrative and teaching issues in Nigeria schools. Owerri: Alphabet Nigeria Publishers.

Adedoyin, F. S. (2008). ICT in the development and sustainability of Nigeria educational system $-2^{\text {nd }}$ National Conference Proceedings. Institute of Education, Olabisi Onabanjo University, Ago-Twoyo, Ogun State, 27-35.

Ajaji, A. I. (2008). Towards effective use of information and communication technology (ICT) for teaching in Nigerian colleges of Education. Asian Journal of Information Technology 7(5) 210-214.

Akuegwu, B. A., Ntukidem, E. P., Ntukidem, P. J.EJaja, G. (2013).Information and communication technology (ICT) facilities utilization for quality instruction service delivery among Universities lecturers in Nigeria, Review of Higher Education in Africa, 3(1), 33-53.

Anaduaka, S. U. and Okafor, C. F. (2013). The universal basic education (UBE) programme in Nigeria: Problems and Prospects. Basic Research Journal of Education, Research and Review 2(3) 42-48.

Asodike, J. D. (2017). Information and Communication Technology facilities in teaching and learning in schools. In C. Williams, J. D. Asodike \& V. N. Duru (Eds). The teaching profession and teaching in a digital world. Port Harcourt: Pearl Publishers. 223-236.

Atanda, A.I. (2009) Classroom management in Education J. B. Babalda and A.D. Ayeni. (Eds) Educational Management Theories and Taks. Lagos; Macmillan Nigeria Publishers. 797-811.

Beqiri, E. (2014). An effective use of information and communication technology in education systems of countries in South East Europe. Academic Journal of Interdisciplinary Studies 3(2), 91-101.

Chao, O. M. (2015). Impact of teacher training on information and communication technology integration in public secondary schools in Mombasa County, Kenya.Human Resource Management Research, 5(4), 77-94.

Duru, V. N. (2017). Teacher effectiveness: Role of Information and Communication Technology (ICT). In W. Cheta, J. D. Asodike \& V. N. Duru (eds). The Teaching Professional \& Teaching in a digital world. Port Harcourt: Pearl Publishers. 130-139.

Ekpoh, U. I. and Etor, C. R. (2012). Academic staff utilization of information and communication technology and knowledge creation in Cross River State Universities. African Higher Education Review 6, 38-52.

Ezekiel, R. P. (2016) ICT facilities Management for Schools' Productivity in S.O. Oluwuo \& J. D. Asodike (Eds). Managing schools for productivity Emerging perspectives. Port Harcourt: Pearl Publishers. 471- 485.

Ghavifekr, S. EWan Rosdv, W. A. (2015). Teaching and learning with technology: Effectiveness of ICT integration in schools. Internationals Journal of Research in Education Science, 1(2),175-19o. 
Ghavifekr, S., Afshari, M., Amla, S. (2012). Management strategies of E-learning system as the core component of systemic change: A qualitative analysis. Life Science Journal, 9(3), 2190-2196.

Grabe, M. (2007).Integrating technology for meaningful learning $\left(5^{\mathrm{lh}} \mathrm{cd}\right.$.). Boston: MA: Houghton Mifflin.

Isah, E. A. and Adediji, A. R. (2016). Information and communication technology (ICT) utilization and management of undergraduate study at the University of Ibadan, Nigeria. International Journal of Educational Administration, Planning and Research (IJEAPR) 8(2) 132-146.

Isangedighi, A. J., Joshua, M. T., Asim, A. E. \& Ekuri, E. E. (2004). Fundamentals ofresearch and statistics in education and social science. Calabar: University of Calabar Press.

National Council for Accreditation of Teacher Education (NCATE, 2002). Professional standard for the accreditation of schools, colleges and Departments of Education, Washington DC:NCATE.

Nwadike, I. S and Godwins, M. (2017). Classroom management in a digital world in W. Cheta J.D. Asodike \& V.N. Duru (eds) The Teaching Profession \& Teaching in Digital world. Port Harcourt: Pearl Publishers. 251-259

Obeten, O. O. and Ekpoh, U. I. (2016). Information and communication technology (ICT) infrastructure and knowledge integration in Nigeria. Evidence from school administrators Education Today 12(1) 202-207.

Ogbonnaya, C. N. (2017). Teaching profession and challenges of ICT in teacher education. In W. Cheta, F. D. Asodike (Eds). The Teaching Profession \& Teaching in Digital World. Port Harcourt: Pearl Publishers. 115-125.

Oko, B. A. \& Uwatt, L. (2015). Information and Communication Technology (ICT) and teachers' performance in terms of lesson preparation and delivery in primary schools in Ogoja Educational Zone of Cross River State. Nigeria. Global Journal of Educational Research.14 (1), 87-92.

Olokoba, A. A., Musa, A. A. and Ajidagba, U. A. (2015). Assessment of ICT on effective management of tertiary institutions in Kwara State, Nigeria. Education for Today 12(1) 300-313.

Oluyemesi, A. O. (2015). ICT and effective school management: Administrators' perspective: Proceedings of the world congress on engineering. London, UK. 1,1-3. Retrieved from: www,iaeng.org/publication/WCE2015/WCE2015_pp249257.

Osaat, D. S. (2013).Record management in schools. The place of Information Communication Technology in J. D. Asodike, J. M. Ebong, S. O. Oluwuo, N. M. Abraham. Contemporary administrative teaching issues in Nigerian schools. Owerri: Alphabet Nigeria Publishers.

Ossai, V. O. \& Isagua, N. M. (2017). ICT and Teacher professional Development in W. Cheta J. D. Asodike \& V.N. Duru (eds) The Teaching Profession \& Teaching in Digital World. Port Harcourt: Pearl Publishers. 54-71.

Plomp, T., Pelgrum, W. J., Law, N. (2007).SITES 2006-International comparative survey of pedagogical practices and ICT in education. Educational and Information Technologies.12 (2), 83-92.

Ratheeswari, K. (2018). Information Communication Technology in Education. Journal of Applied and Advanced Research.3 (1), 45-47.

Sigh, T. K. R. and Muriadi, K. (2012). Factors affecting school administration choice in adopting ICT tools in schools. International Education Studies 5(4), 20-30.

Ubabudu, M. C. N, and Muraina, A. I. (2016). The impact of adoption and use of information and communication technology on pre-service teachers in colleges of education in Lagos State. International Journal of Educational Administration, Planning and Research (IJEAPR) 8(1) 192-207.

Ukala, C. C. \& Nwabueze, A. I. (2015). School administration and supervision in F. N. Obasi, S. D. Oluwuo, J. D.; Asodike and S. C. Anyomaele (Eds). Leadership in school productivity. Emerging Perspective Port Harcourt Pearl Publishing International, 98-115.

UNESCO (2002).Information and Communication Technology in Education - A Curriculum for Schools and Programme for Teacher Development. Paris: UNESCO.

Wanjohi, T. G. (2011). The influence ofInformation and Communication Technology (ICT) on the service delivery of teachers in public secondary schools, Nyeri County, Kenya. Unpublished MBA Thesis, School of Business, Kenyatta University, Kenya.

Williams, R. E., Uchendu, C. C. and Mbon, U. F. (2014). Information and communication technology facilities and public secondary school work performance in Akwa Ibom State, Nigeria. International Journal of Educational Administration Planning and Research 6(1), 71-81. 